\begin{tabular}{lccccc} 
GEC UGI Ulcers + Ulcer & Celecoxib & 6 & 0.32 & 0.25 & 0.006 \\
Complications & & & & $(0.09$, & \\
& & & & $0.67)$ & \\
& NSAIDs & 12 & 1.27 & - & - \\
\hline
\end{tabular}

*Per $100 \mathrm{pt}$ yr exposure (duration from first dose to hospitalisation, or to last contact); celecoxib: 1883 pt-yrs, NSAIDs: 942 pt-yrs.

Conclusion UGI hospitalisation rates were $2-4 \mathrm{x}$ lower, and less UGI-related healthcare resources were utilised for celecoxib- vs NSAID-treated patients. The incidence of serious clinical UGI safety endpoints was significantly lower in the celecoxib-treated patients. Sponsored by Pharmacia Corporation and Pfizer, Inc.

\section{SAT0098 COX-2 SPECIFIC INHIBITORS - IS THERE ANY BENEFIT OF USING THESE AGENTS IN PATIENTS ON LOW DOSE ASPIRIN (ASA)?}

${ }^{1} \mathrm{G}$ Singh, ${ }^{2} \mathrm{~J}$ Goldstein, ${ }^{3} \mathrm{~N}$ Agrawal, ${ }^{4} \mathrm{G}$ Eisen, ${ }^{5} \mathrm{~W}$ Stenson, ${ }^{6} \mathrm{~J}$ Fort, ${ }^{6} \mathrm{~A}$ Bello, ${ }^{6} \mathrm{~S}$ Boots. ${ }^{1}$ Department of Medicine, Stanford University, Palo Alto; ${ }^{2}$ Department of Medicine, University of Illinois at Chicago, Chicago; ${ }^{3}$ Division of Gastroenterology, Duke University, Durham; ${ }^{4}$ Division of Gastroenterology, Vanderbilt University School of Medicine, Nashville; ${ }^{5}$ Division of Gastroenterology, Washington University, St. Louis; ${ }^{\circ}$ Pharmacia, Peapack, NJ, USA

\subsection{6/annrheumdis-2001.473}

Background COX-2 specific inhibitors have been shown to significantly reduce the risk of gastrointestinal complications compared to conventional NSAIDs, while providing equivalent efficacy. However, there is significant controversy regarding the UGI safety and tolerability benefits of COX-2 specific inhibitors, such as celecoxib, in patients on concomitant low-dose ASA ( $<325 \mathrm{mg} /$ day) for cardiovascular protection.

Objectives To evaluate the UGI tolerability and safety of celecoxib 200 or $400 \mathrm{mg}$ per day and the commonly prescribed conventional NSAIDs (diclofenac or naproxen) in patients taking ASA in SUCCESS-1, a large multinational double-blind, randomised study.

Methods SUCCESS-1 enrolled 13,274 patients from 1,142 centres in 39 countries in Europe and South Africa, Asia, Latin America, and the US and Canada. Patients were treated for 12 weeks using celecoxib (200 or $400 \mathrm{mg} / \mathrm{d}$ ) and NSAIDs (naproxen $1000 \mathrm{mg} / \mathrm{d}$ in US and Canada and diclofenac $100 \mathrm{mg} / \mathrm{d}$ in all other countries). Adverse events were captured at week 6 and week 12 using standard adverse assessment ascertainment. In addition, all investigator-identified potentially clinically significant UGI events were referred to an independent Gastrointestinal Events Committee (GEC), which reviewed all data in a blinded fashion. Events were categorised as UGI ulcer complications (perforations, gastric outlet obstruction, bleeding), symptomatic UGI ulcerations or other GI events.

Results Of the 13,194 patients randomised in the SUCCESS-1 trial, 4421 and 4429 patients received 200 or $400 \mathrm{mg}$ per day of celecoxib respectively, 914 patients received $1000 \mathrm{mg}$ per day of naproxen, and 3510 patients received $100 \mathrm{mg}$ per day of diclofenac. Patients were mostly female (67\%), and $42 \%$ were 65 years or older (mean age: 62 years). Patients in each group had comparable baseline aspirin use and past history of upper GI (UGI) bleeding. A total of 697 patients took celecoxib and ASA. In the NSAID arm, 348 patients took concomitant ASA.

\begin{tabular}{|c|c|c|c|c|c|}
\hline & $\begin{array}{l}\text { UGI } \\
\text { SAFETY }\end{array}$ & $\begin{array}{l}\text { Celecoxib } \\
\text { and ASA } \\
(n=697)\end{array}$ & $\begin{array}{l}\text { NSAIDs } \\
\text { and } \\
\text { ASA } \\
\text { (n = } \\
348 \text { ) }\end{array}$ & $\begin{array}{l}\text { Celecoxib } \\
\text { without } \\
\text { ASA } \\
(\mathrm{n}=8103)\end{array}$ & $\begin{array}{l}\text { NSAIDs } \\
\text { without } \\
\text { ASA } \\
\text { ( } \mathrm{n}= \\
4046)\end{array}$ \\
\hline \multicolumn{6}{|c|}{$\begin{array}{l}\text { Serious UGI events/100 } \\
\text { pt yrs ( } n)\end{array}$} \\
\hline $\begin{array}{l}\text { Possible UGI events } \\
\text { (investigator } \\
\text { determined) }\end{array}$ & & $10(13)$ & $\begin{array}{l}17.4 \\
(11)\end{array}$ & $4.4(70)$ & $6.3(50)$ \\
\hline $\begin{array}{l}\text { Confirmed Ulcer } \\
\text { complications }\end{array}$ & & $0.8(1)$ & $1.6(1)$ & $0.1(1)$ & $0.8(6)$ \\
\hline $\begin{array}{l}\text { Confirmed Ulcer } \\
\text { complications/ } \\
\text { symptomatic ulcers }\end{array}$ & & $2.3(3)$ & $6.3(4)$ & 0.9 (15) & $1.8(14)$ \\
\hline
\end{tabular}

Conclusion Risk reduction with celecoxib and ASA is lower than risk reduction in patients not taking ASA. However, the magnitude of this risk reduction is clinically significant. Therefore, celecoxib continues to have a role in reducing risk of UGI complications even in patients on low dose ASA.

\section{Metabolic and crystal arthropathies}

\section{AB0152 THE DIFFERENTIAL DIAGNOSTIC SPECIFICITIES OF PURINE ENZYMES ACTIVITY IN RHEUMATOID ARTHRITIS AND GOUT}

AB Zborovsky, VF Martemyanov, MY Stazharov, SA Bedina, EE Mozgovaya. Laboratory for Clinical Biochemistry, Research Institute for Clinical and Experimental Rheumatology, Volgograd, Russia

\subsection{6/annrheumdis-2001.474}

Background The clinical picture of gouty arthritis (GA) and rheumatoid arthritis (RA) can be quite often much alike, and the differential diagnosis of these diseases is rather difficult. The GA and RA patients often have hyperuricemia, which is indicative of purine metabolism breaches in patients with these diseases.

Objectives To study differential diagnostic specificity of Purine enzymes activity in Rheumatoid arthritis and Gout.

Methods We observed 71 RA patients. The mean age of the patients ? $43.2 \pm 3.6$ years. The mean duration of the disease $11.9 \pm 3.6$ years. I degree of RA activity was determined in 17 (23.94\%), II ? in 44 (61.97\%), III ? in 10 (14.09\%) observations. 34 Gout patients were examined. The mean age of the patients ? $48.2 \pm 2.2$ years. The mean duration of the disease $8.8 \pm 1.3$ years. The intermittent form of Gout was determined in $21(61.8 \%)$, the chronic form ? in 13 (38.2\%) observations. Adenosin deaminase (ADA), AMP-desaminase (AMPDA), Xanthine dehydrogenase (XDG), Xanthine oxidase (XO) activities were measured with spectrophotometer, ADA, XDG isoenzymes were examined with method of electrophoresis in agarose gel and obtained enzymograms were evaluated at densitometry.

Results XDG activity was more high, XO/XDG activities ratio was less in Gout patients in comparison with RA patients (I 